Arab Univ. J. Agric. Sci., Ain Shams Univ., Cairo, Egypt

29(1), 197 - 210, 2021

Website: http://ajs.journals.ekb.eg

DOI: $10.21608 /$ ajj.2021.48681.1288

\title{
Design of Sprinkler Irrigation Systems Using an Expert System Program
}

\author{
Mohamed G Alashram ${ }^{1 *}$, Khaled F Elbagoury ${ }^{2}$, Said M Shaaban ${ }^{1}$,
}

Ahmed A Abdel-Aziz ${ }^{2}$

1- Water Relations and Field Irrigation Dept, National Research Centre, Dokki, Giza, Egypt

2- Agric Engineering Dept, Fac of Agric, Ain Shams Univ, P.O. Box 68-Hadayek Shoubra 11241, Cairo, Egypt

*Corresponding author: alashram.mgmnrc@yahoo.com

Received 6 November, 2020

Accepted 18 January, 2021

\begin{abstract}
In this research, a rule-based expert system named EFSIS-ES (Engineering Factors of Sprinkler Irrigation System -Expert System) had been built, verified and validated. Therefore, the aims of this research were to build, verify and validate an expert system for making a decision for the normal user to maximize system efficiency of sprinkler irrigation. The inputs data included location data, climate data, pump data, crop data, soil data and sprinkler system data. The outputs of the expert system were number of the sprinklers on a lateral, number of laterals in the irrigation system, length of each lateral, main line length, irrigation frequency, required pump power, total dynamic head (TDH) and pump discharge output. Results showed high correlation $\left(\mathrm{R}^{2}=0.9927\right)$ between the EFSIS-ES program and the designed spreadsheet in regard to irrigation frequency. It could be indicated high correlation $\left(\mathrm{R}^{2}=0.9999\right)$ between the EFSIS-ES program and the designed spreadsheet regarding pump power. The regression coefficient $\left(\mathrm{R}^{2}\right)$ was 0.9983 between EFSIS-ES program and SSSDPS Expert regarding total dynamic head (TDH). It could be indicated high correlation $\left(\mathrm{R}^{2}=0.9979\right)$ between EFSIS-ES program and
\end{abstract}

SSSDPS Expert regarding pump discharge output.

Keywords: Expert system; EFSIS-ES Program; Sprinkler irrigation; Smart irrigation technology; Pump power; Irrigation frequency.

\section{Introduction}

Computer models are strong tools to plan and design water distribution for irrigation systems. Computer models were developed for simulating flow rate and pressure distribution along laterals and pipes of irrigation system. The hydraulic performance of sprinkler is the main factor in designing sprinkler irrigation lateral because of pressure change along sprinkler irrigation lateral with the discharge. Therefore, water distribution varies into the field (Van de Giesen et al 2011). Water is necessary for plant growth; furthermore, water available for irrigation is limited. So, modern irrigation system should be applied. However, water shortage was subject to increase stress on how to effectively and reasonably allocation irrigation water resources for promoting sustainable development of irrigation zone ( $\mathrm{Li}$ et al 2016). Decision making is an inherently 
human activity that can have significant impacts. It is perhaps not surprising that researchers have attempted to improve the quality of decisions by developing computer technologies to augment and extend human capabilities. Advances in Artificial Intelligence (AI) have made this goal a reality in many applications. These AI-integrated decision making support systems, or intelligent decision support systems (IDSS) for short, are increasingly used to assist decision making in such areas as finance, healthcare, marketing, commerce, command and control, and cybersecurity (Phillips-Wren 2012). Expert system (ES) is an artificial intelligence applications of computer program that "can make a replica of human capacity for logical thinking based on some rules and facts presented to it" (Shervan et al 2013) and "can be designed by human experts for transferring their knowledge that they know to other people who need this knowledge" (Motameni 2010). Today, expert system supports several problems by solving activities like decision making, designing, planning, knowledge fusing, forecasting, regulating, monitoring, identifying, controlling, diagnosing, prescribing, explaining, interpreting, and training by using different techniques. Expert systems of the future expected of them supporting more activities (Khamkar 2014).

The idea of building expert system is coding knowledge using computer program so it can be consulted in the same trend that one consults the human expert. Professionally designed expert systems simulate the logical thinking process of human experts for solving specific problems and non-experts can use them for improving their capabilities in problem-solving. Also, all experts can use it as knowledgeable assistants (Gutierrez-Estrada et al 2005). Because of the succession of the technology of expert system in solving many problems in the agricultural sector of Egypt, researchers' of agricultural water had conducted many efforts for improving different practices efficiency of agricultural water using technology of expert system. And also hereby different expert systems programs were developed such: the ISS-ES (Irrigation System Scheduling-Expert System) that was developed according to El-Bagoury (2004); the CHEMIGAT-ES (Chemigation-Expert System) that was developed according to Doukhan (2010); the IMOC-ES (Irrigation Management for some Oil Crops-Expert System) that was developed according to El-Tohamy (2016); the TSDI-ES (Technical Specifications of Drip Irrigation-Expert System) that was developed according to Ragab (2017) and the ISM-ES (Irrigation Systems Management-Expert System) that was developed according to Eid and Abdrabbo (2018).

Sprinkler irrigation is recognized as one of the widely popular methods for irrigating agricultural lands. The working of those systems has increased consequently to their benefits. Accordingly, for addressing the case of improving sprinkler irrigation performance and raising the efficiency of the systems in different domains has been remarkable. Such a helpful study in this respect is a review of the performance of various sprinklers considering different arrangements, sprinklers spaces and chosen of most suitable sprinkler for every regional wind speed events (Seraj-Rezaei et al 2014). The basic target of sprinkler irrigation method, like the other irrigation methods, is applying irrigation water uniformly in effective root zones. The uniform distribution in sprinkler irrigation based on factors like the operating pressure, the sprinklers arrangement, sprinkler type, nozzles size, nozzles number, wind velocity and wind direction. Sprinkler and lateral space should be calculated using wind velocity and wind direction. Water distribution and application limits were determined with using different operating pressures, nozzle diameters, and spatial arrangement under area conditions by using some of irrigation sprinklers that were commonly used (Kara et al 2008). The aims of this research were to build, verify and validate an expert system for making a decision for the normal user to maximize system efficiency of sprinkler irrigation. 


\section{Materials and Methods}

\subsection{Building up of EFSIS-ES program}

In this research, a rule-based program named EFSIS-ES (Engineering Factors of Sprinkler Irrigation System -Expert System) was coded and compiled using Microsoft visual basic 2015 language which represents a part of the Microsoft Visual studio Express 2015 for windows Desktop Package. The flowchart shows the key inputs, data processing and outputs for the EFSIS-ES rulebased program as shown in Fig 1.

\subsubsection{User interface}

A graphic user interface (GUI) is designed to have a clear and soft feel to advance easy use for both experienced users and novice researchers and farmers for supporting them with decision-making to easily design the system of sprinkler irrigation by choosing the proper engineering specifications.

\subsubsection{Structure of EFSIS-ES}

\section{a. Conceptualization}

All concepts that entered step-by-step for building up such as location, climate, pump, crop, soil and sprinkler system had been considered.

\section{b. Formalization}

The parameters such as: (location, climate, pump, crop, soil and sprinkler system) were the most considered for system of sprinkler irrigation design. These parameters had been investigated depended on number of rules and factors by using specific equations.

\subsection{Description of the EFSIS-ES program}

Inputs screens are the interface screen, inputs screen, location screen, climate screen, pump screen, crop screen, soil screen and sprinkler system screen. The interface screen contains interface of meaning of abbreviation EFSIS-ES rule-based program.
The inputs screen as shown in Fig 2 contains menus strips of (location, climate, pump, crop, soil and sprinkler system) and some information about the authors of the program, in addition, run and close action buttons of the program.

Location screen contains district name (Anuradhapura), length of field $(50 \mathrm{~m})$, width of field $(20 \mathrm{~m})$ and available irrigation time (7hr/day).

The climate screen contains average air temperature $\left(28^{\circ} \mathrm{c}\right)$, average relative humidity $(60 \%)$, average wind speed $(6 \mathrm{~km} / \mathrm{hr})$ and evapotranspiration rate $(7 \mathrm{~mm} /$ day $)$.

The pump data screen contains the distance to the water source from the pump $(10 \mathrm{~m})$, static head of water source from soil surface (7m) and type of water source (canal).

The crop screen contains name of crop (Tomato), peak period Kc value (1.15), the height of crop $(0.6 \mathrm{~m})$ and root zone depth $(1.5 \mathrm{~m})$.

The soil screen that contains the texture of soil (loam), soil slope $(0.0024 \mathrm{~m} / \mathrm{m})$, infiltration rate $(65 \mathrm{~mm} / \mathrm{hr})$, field capacity $(200 \mathrm{~mm} / \mathrm{m})$ and permanent wilting point $(50 \mathrm{~mm} / \mathrm{m})$.

Sprinkler system screen as shown in Fig 3 contains sprinkler type (Bladespl), operating pressure (2bar), spacing between sprinklers $(7 \times 7 \mathrm{~m})$, nozzle diameter $(2.5 \mathrm{~mm})$, flow rate of sprinkler $\left(0.6 \mathrm{~m}^{3} / \mathrm{hr}\right)$, uniformity coefficient (76\%), type of pipe (LDPE) and the diameter of main line $(75 \mathrm{~mm})$.

The outputs screen displays number of sprinklers in a lateral (2), number of laterals in the irrigation system (16), length of each lateral $(10 \mathrm{~m})$, main line length $(46.5 \mathrm{~m})$, irrigation frequency (16 day), required pump power (1.724 hp), total dynamic head (TDH) (24.668 $\mathrm{m})$ and pump discharge output $\left(19.436 \mathrm{~m}^{3} / \mathrm{hr}\right)$.

\subsection{Verification and validation of the EFSIS-ES program}

Verification is like debugging, it is purposed for ensuring that developed expert systems do what they are intended to do. Results obtained by the EFSIS-ES program were compared with personally designed spreadsheet as a verification step. The results of EFSIS-ES 


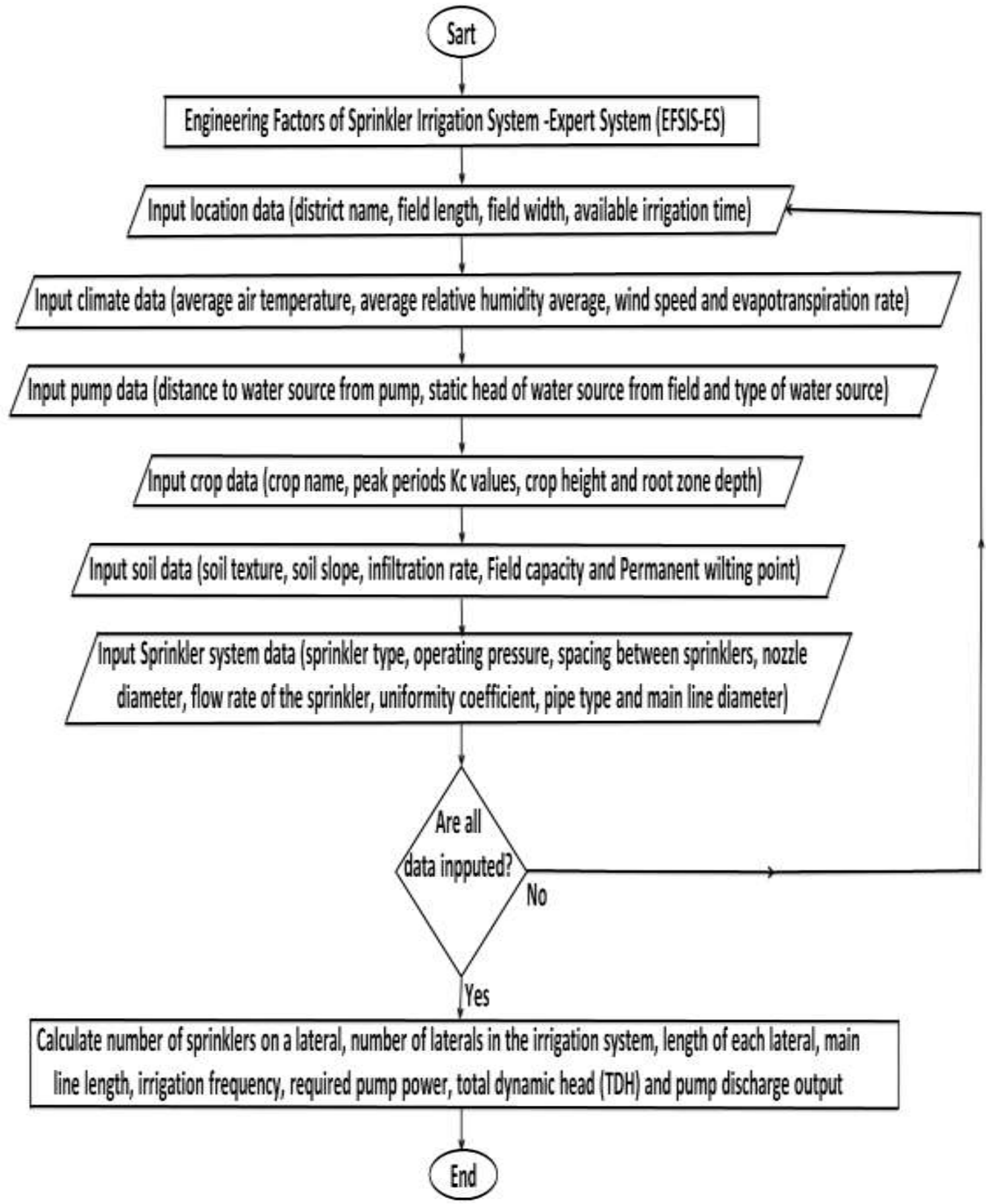

Fig 1. The EFSIS-ES program flowchart 


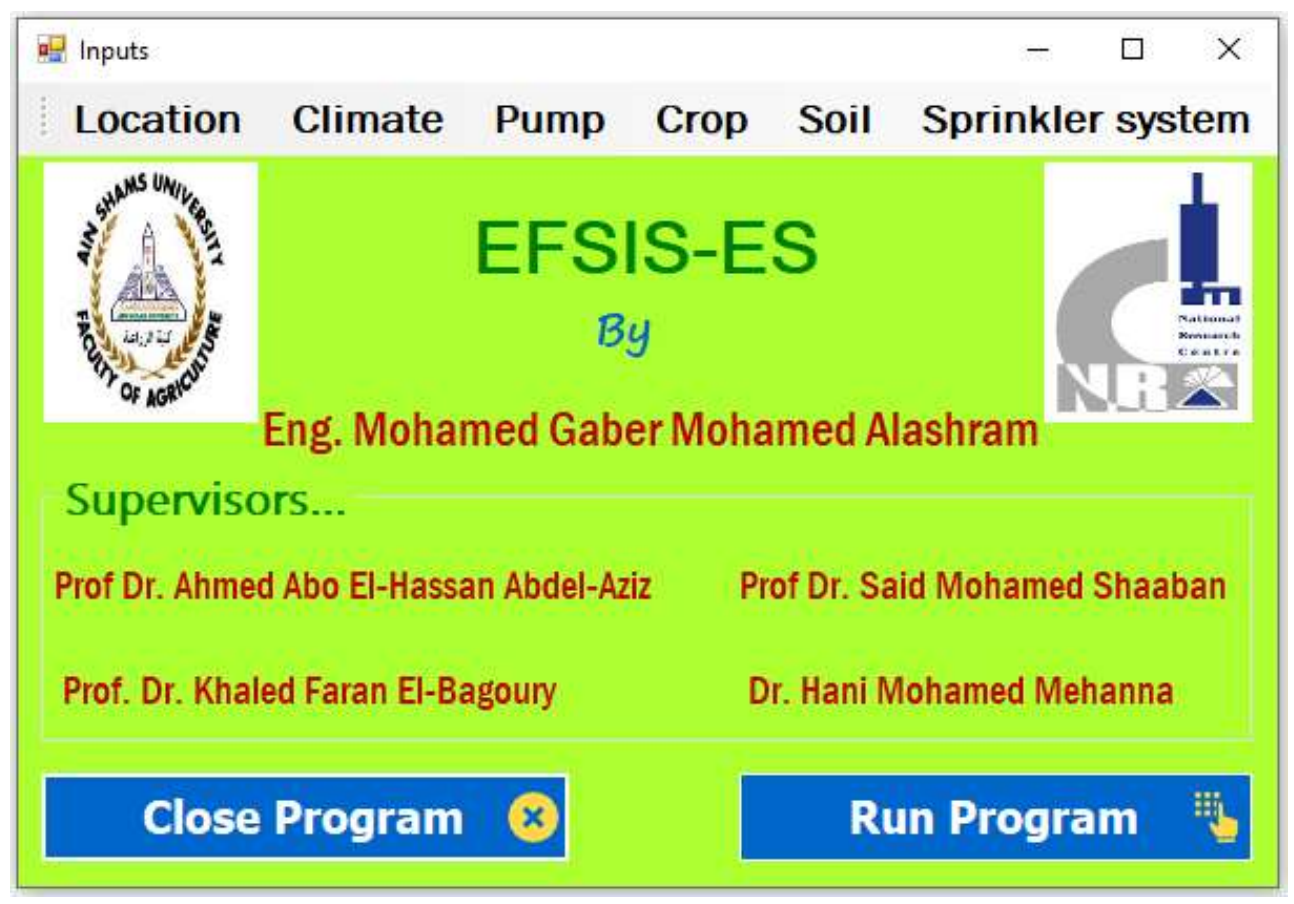

Fig 2. Briefing of the EFSIS-ES program

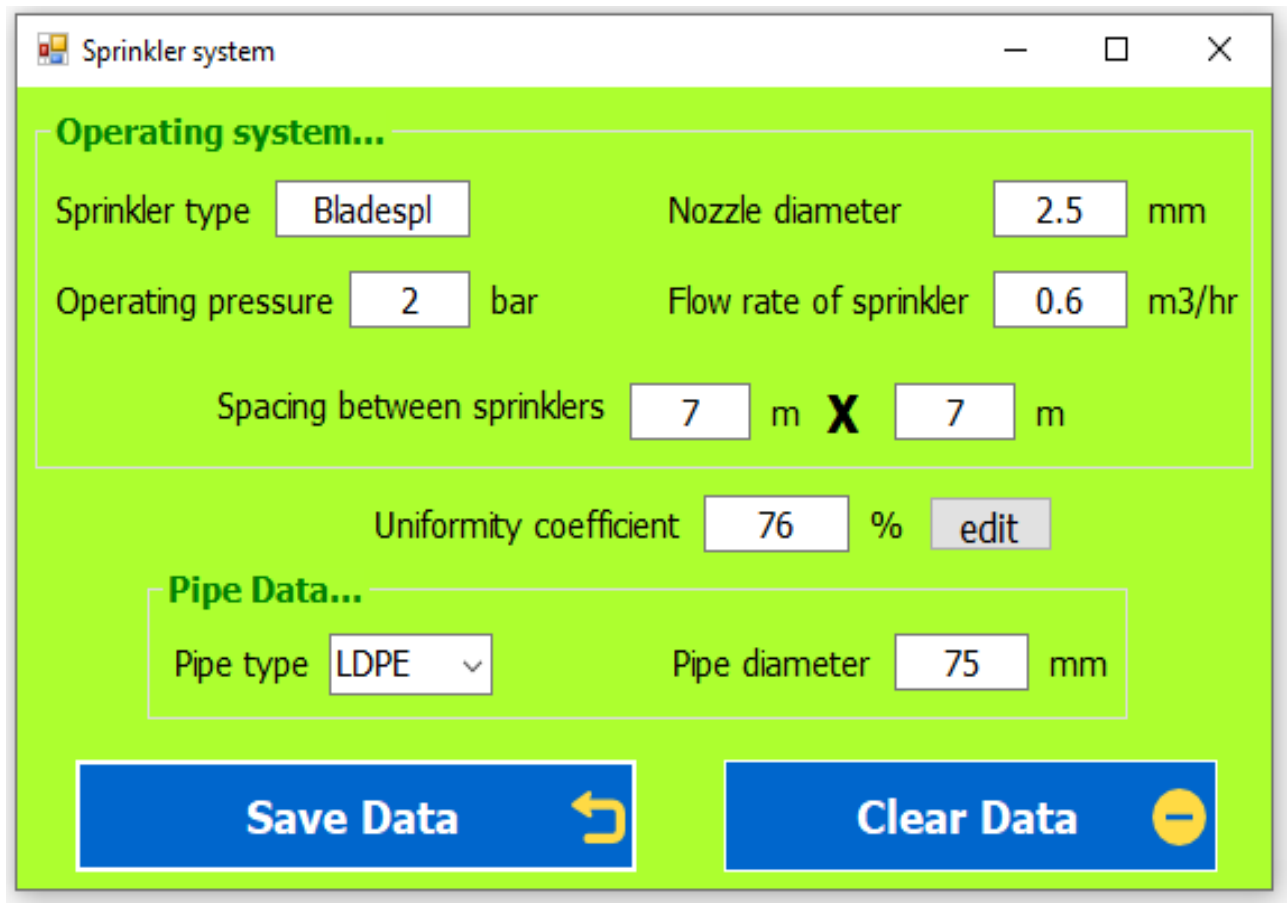

Fig 3. Technical data screen of the EFSIS-ES program 
program were compared with other Expert system noted as SSSDPS Expert (Simple Sprinkler System Designing and Pump Selection Expert), which was developed by Abeyrathne et al (2005) as a validation step.

\subsection{The formulae used in building up the program}

\subsubsection{Irrigation water requirement}

The irrigation water requirements (NWR) for the area are given by (Cuenca 1989):

$$
\begin{array}{r}
N W R=(\theta f c-\theta p w p) * R D \\
* M A D \ldots(1)
\end{array}
$$

Where, NWR are irrigation water requirements $(\mathrm{mm}), \theta_{\text {fc }}$ is field capacity $(\mathrm{mm} / \mathrm{m}), \theta_{\text {pwp }}$ is permanent wilting point $(\mathrm{mm} / \mathrm{m}), \mathrm{RD}$ is root zone depth $(\mathrm{m})$ and MAD is maximum allowable depletion (\%).

\subsubsection{Irrigation frequency}

The irrigation frequency $\left(T_{i}\right)$ was calculated by (Cuenca 1989):

$$
T_{i}=\frac{N W R}{E T_{C}}
$$

Where, $T_{i}$ is irrigation frequency (day), NWR are irrigation water requirements $(\mathrm{mm})$ and $\mathrm{ET}_{\mathrm{c}}$ is crop evapotranspiration ( $\left.\mathrm{mm} / \mathrm{day}\right)$.

\subsubsection{Irrigation system capacity}

Irrigation system capacity (Q) is continuous discharge rate requiring for irrigation that was calculated using (Cuenca 1989):

$$
Q=\frac{2.778\left(i_{g} \times A\right)}{N_{o p} \times T_{o p}}
$$

Where, $\mathrm{Q}$ is irrigation system capacity $(1 / \mathrm{s}), \mathrm{i}_{\mathrm{g}}$ are total irrigation requirements $(\mathrm{mm}), \mathrm{A}$ is total irrigation area (ha), $N_{o p}$ is operating days for irrigation frequency (day) and $\mathrm{T}_{\mathrm{op}}$ is operating hours in day (hr/day).

\subsubsection{Total dynamic head}

\section{a. Fixed system head}

The fixed system head $\left(\mathrm{h}_{\mathrm{fix}}\right)$ was calculated by (Cuenca 1989):

$$
h_{f i x}=h_{z s}+h_{z d}
$$

Where, $\mathrm{h}_{\mathrm{fix}}$ is fixed system head $(\mathrm{m}), \mathrm{h}_{\mathrm{zs}}$ is static head on the pump suction side (m) and $\mathrm{h}_{\mathrm{zd}}$ is static head on the pump discharge side (m).

\section{b. Variable system head losses}

The variable system head losses $\left(\mathrm{h}_{\mathrm{var}}\right)$ were calculated by using (Cuenca 1989):

$$
h_{v a r}=S_{w e l l}+h_{f}+h_{p}+\frac{v^{2}}{2 g} \ldots \ldots \ldots \ldots
$$

Where, $\mathrm{h}_{\text {var }}$ is variable system head losses $(\mathrm{m})$, $S_{\text {well }}$ is well drawdown $(\mathrm{m}), \mathrm{h}_{\mathrm{f}}$ is all friction head losses in fittings and main line $(\mathrm{m}), \mathrm{h}_{\mathrm{p}}$ is pressure head at critical discharge point in the distribution system (m), $V$ is velocity at critical discharge point in the distribution system $(\mathrm{m} / \mathrm{s})$ and $\mathrm{g}$ is gravity acceleration $\left(\mathrm{m} / \mathrm{s}^{2}\right)$.

\section{c. Total dynamic head}

Total dynamic head (TDH) of pump was found using (Cuenca 1989):

$$
\mathrm{TDH}=\mathrm{h}_{\mathrm{fix}}+\mathrm{h}_{\mathrm{var}}
$$

Where, TDH is total dynamic head $(\mathrm{m}), \mathrm{h}_{\text {fix }}$ is fixed system head (m) and $h_{\text {var }}$ is variable system head (m).

\subsubsection{Required pump power}

Required pump power (P) was calculated by using (Cuenca 1989): 


$$
P=\frac{Q \times H \times S_{g}}{4634 E}
$$

Where, $\mathrm{P}$ is required pump power (hp), $\mathrm{Q}$ is pump flow $(1 / \mathrm{min}), \mathrm{H}$ is flow head $(\mathrm{m}), \mathrm{S}_{\mathrm{g}}$ is fluid specific gravity and $\mathrm{E}$ is pump efficiency $(\%)$.

\section{Results and Discussion}

\subsection{Verification of the Expert System}

Fig 4 illustrates irrigation frequency calculated by the EFSIS-ES program comparing with the calculated by personally designed and verified spreadsheet. It could be indicated high correlation $\left(\mathrm{R}^{2}=0.9927\right)$ between the EFSISES program and the designed spreadsheet in regard to irrigation frequency. The pump power calculation using the EFSIS-ES program against the personally designed spreadsheet had been shown in Fig 5. It could be indicated high correlation $\left(\mathrm{R}^{2}=0.9999\right)$ between the EFSIS-ES program and the designed spreadsheet regarding pump power.

Comparisons were made between EFSISES against the personally designed spreadsheet for the study factors of this research regarding total dynamic head (TDH) as shown in Figs 6, 7 and 8. It is clear that total dynamic head (TDH) which gained using the EFSIS-ES and that calculated by the personally designed spreadsheet are almost the same. It could be indicated high agreement between the EFSISES program and the personally designed spreadsheet.

\subsection{Validation of the Expert System}

Data presented in Figs 9 and 10 indicated that the regression analysis between EFSIS-ES program and SSSDPS Expert regarding (total dynamic head (TDH) (m) - pump discharge output $\left.\left(\mathrm{m}^{3} / \mathrm{hr}\right)\right)$. The regression coefficient $\left(\mathrm{R}^{2}\right)$ was 0.9983 between EFSIS-ES program and SSSDPS Expert regarding total dynamic head (TDH). It could be indicated high correlation $\left(\mathrm{R}^{2}=0.9979\right)$ between EFSIS-ES program and SSSDPS Expert regarding pump discharge output.

A comparison was made between data calculated using EFSIS-ES program against SSSDPS Expert. When we compare values of Fig 11 with Fig 12, it could be concluded a high agreement among values of the two expert systems. It is also clear that value of total dynamic head (TDH) calculated by EFSIS-ES program $(24.67 \mathrm{~m})$ was in closer agreement with the SSSDPS Expert $(24.64 \mathrm{~m})$, and also the value of pump discharge output calculated by EFSIS-ES program $\left(19.24 \mathrm{~m}^{3} / \mathrm{hr}\right)$ was in closer agreement with SSSDPS Expert (19.44 $\mathrm{m}^{3} / \mathrm{hr}$ ).

The above mentioned observed data indicate the ability of applying computer program technology for designing sprinkler irrigation system under specified field conditions with high accuracy of investigation. This means that, the maximization of on-farm irrigation water unit could be achieved by applying EFSIS-ES program. 


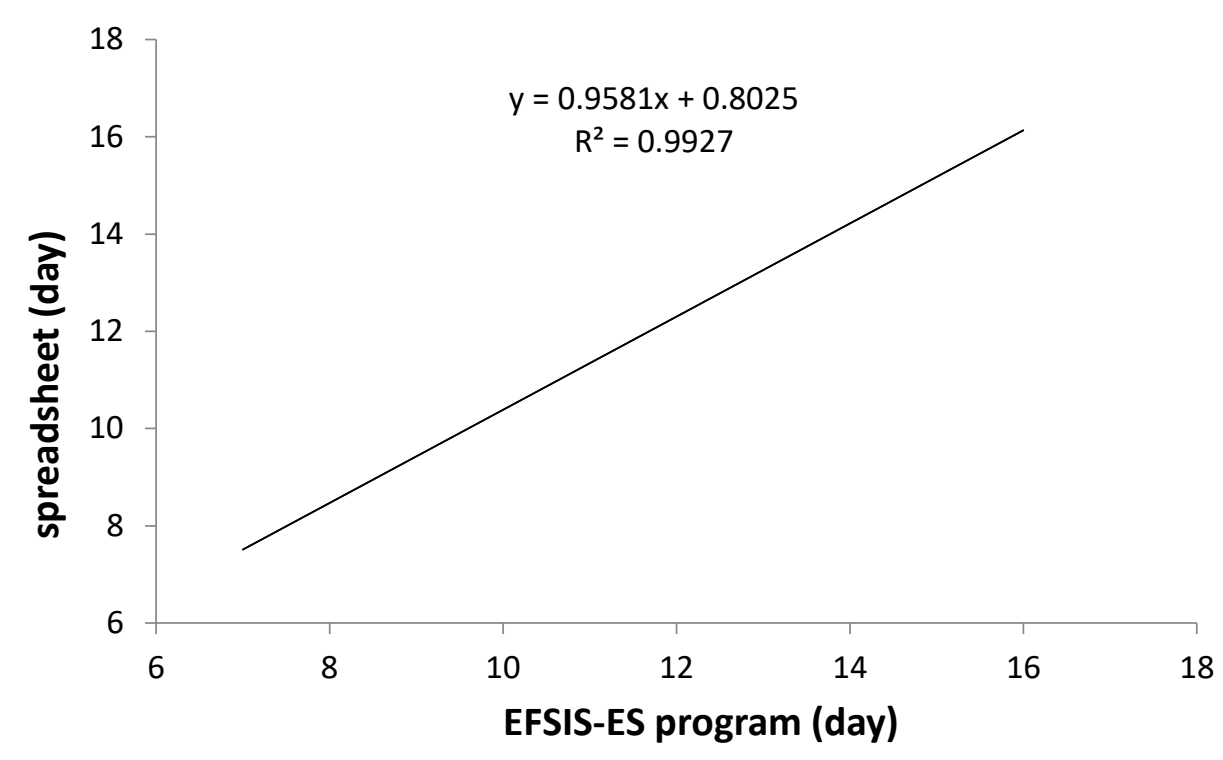

Fig 4. Correlation analysis of irrigation frequency (day) using EFSIS-ES program against the personally designed spreadsheet

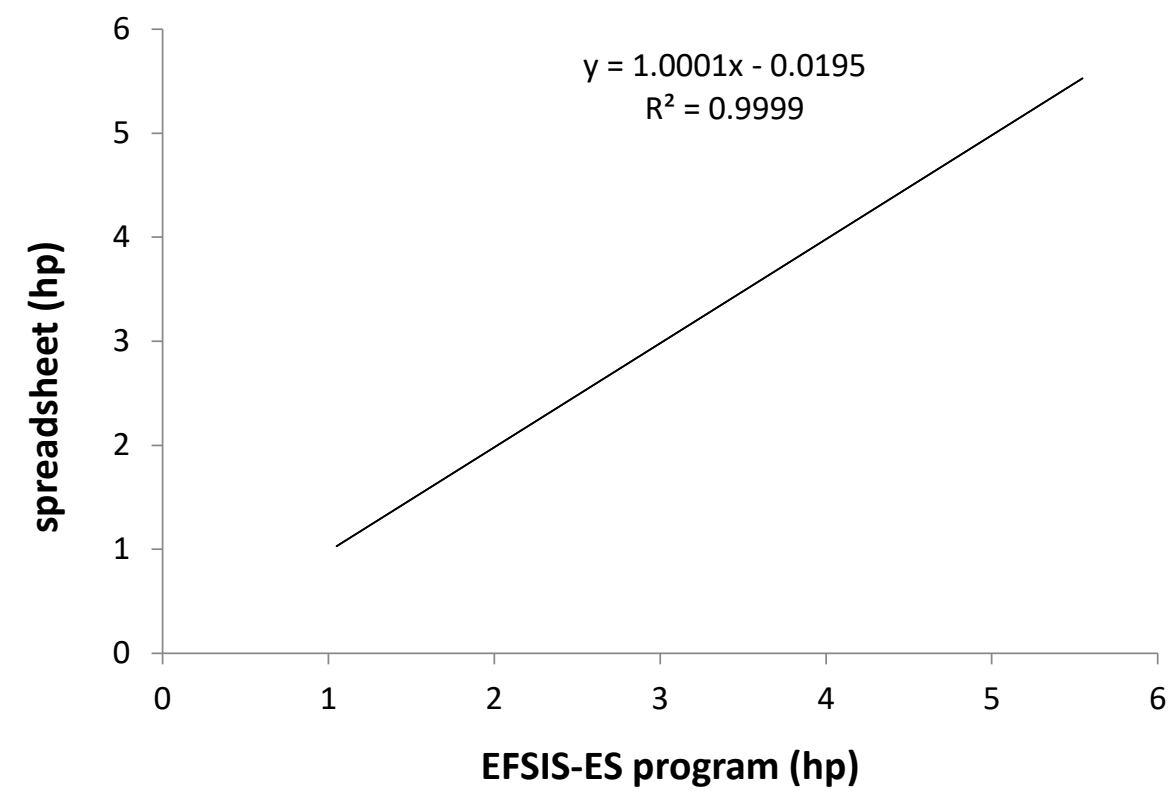

Fig 5. Correlation analysis of required pump power (hp) using EFSIS-ES program against the personally designed spreadsheet 


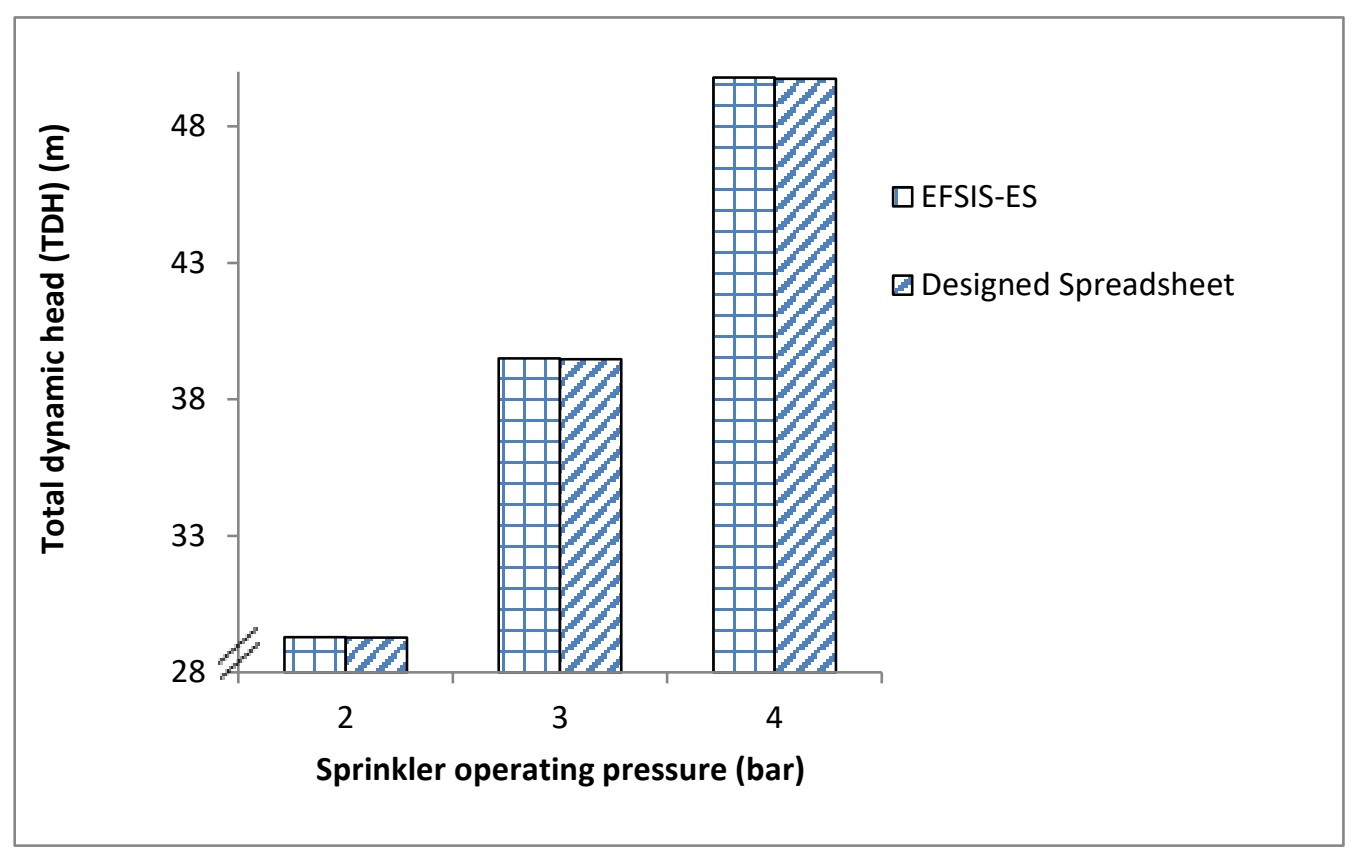

Fig 6. A comparison between EFSIS-ES against the personally designed spreadsheet for the factor of sprinkler operating pressure regarding total dynamic head (TDH)

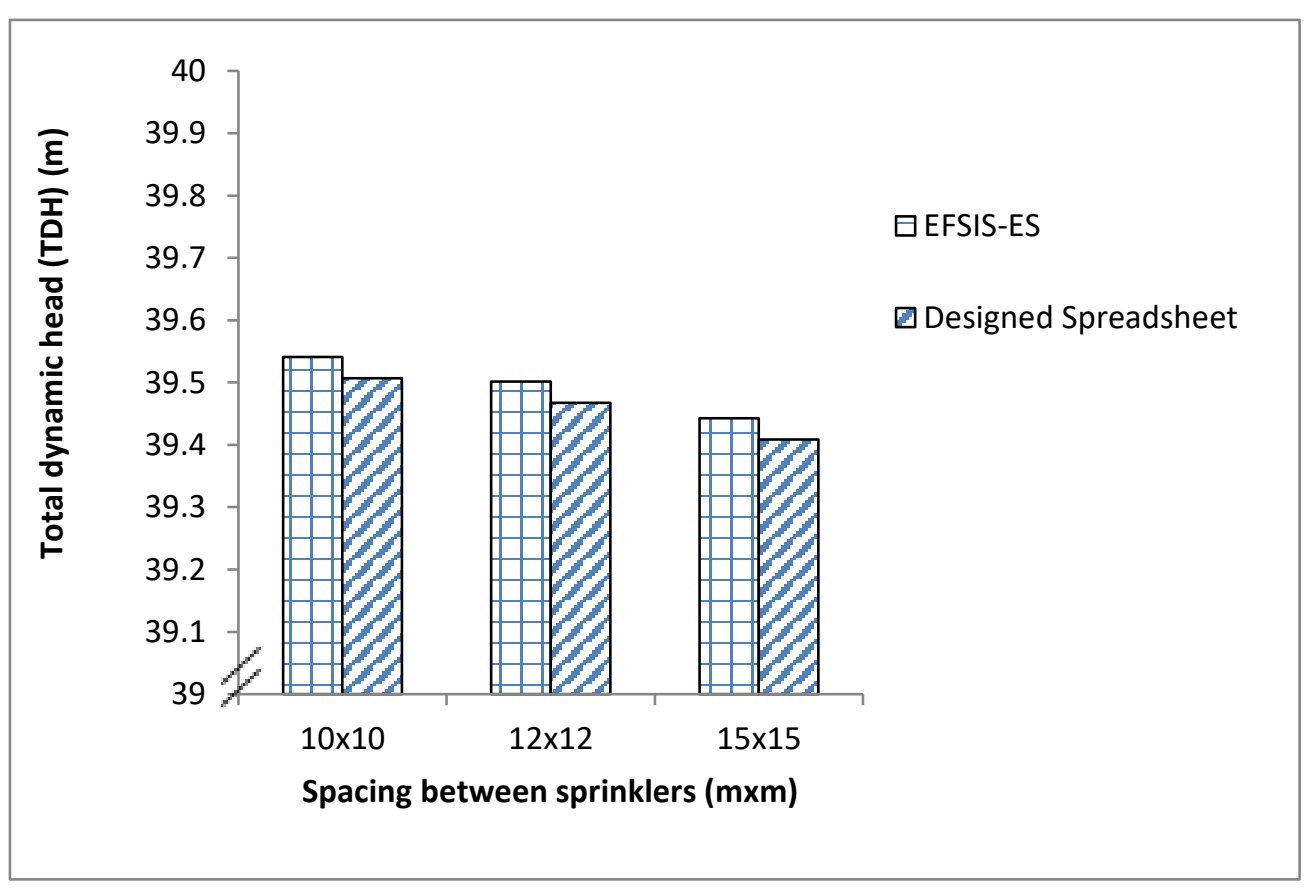

Fig 7. A comparison between EFSIS-ES against the personally designed spreadsheet for the factor of spacing between sprinklers regarding total dynamic head (TDH) 


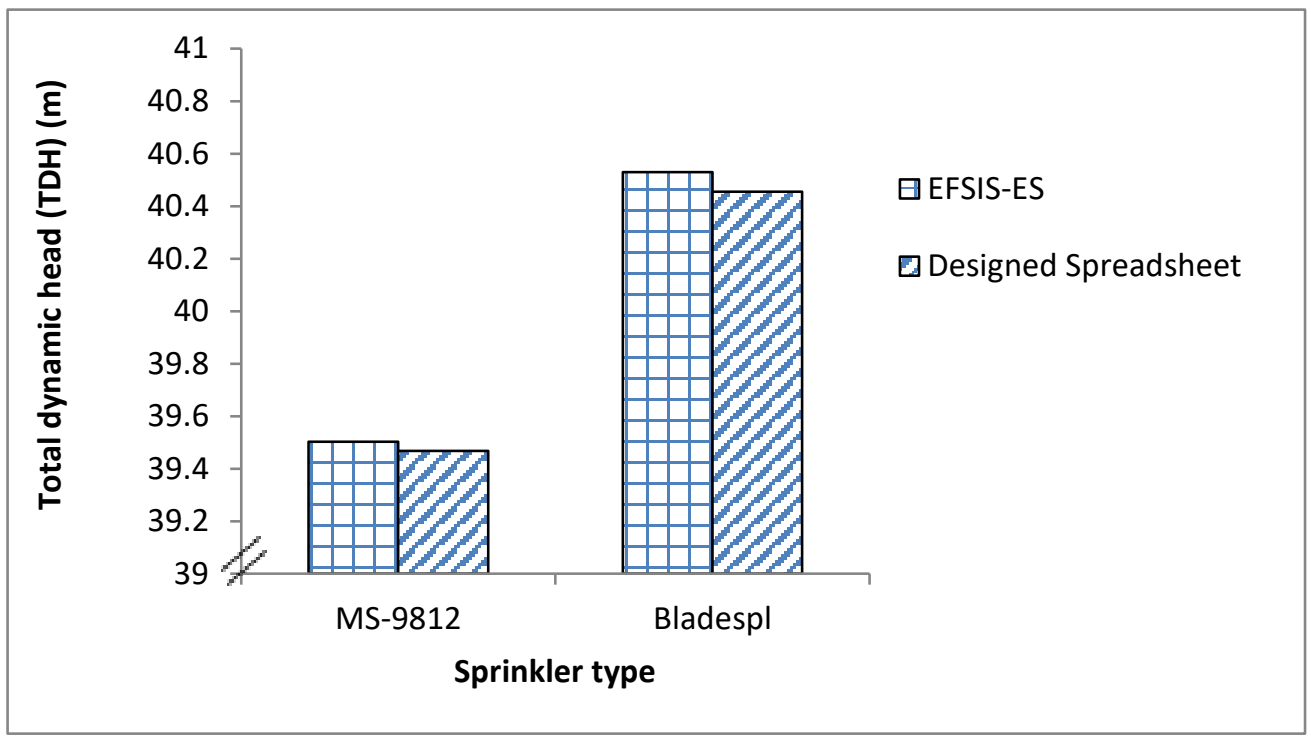

Fig 8. A comparison between EFSIS-ES against the personally designed spreadsheet for the factor of sprinkler type regarding total dynamic head (TDH)

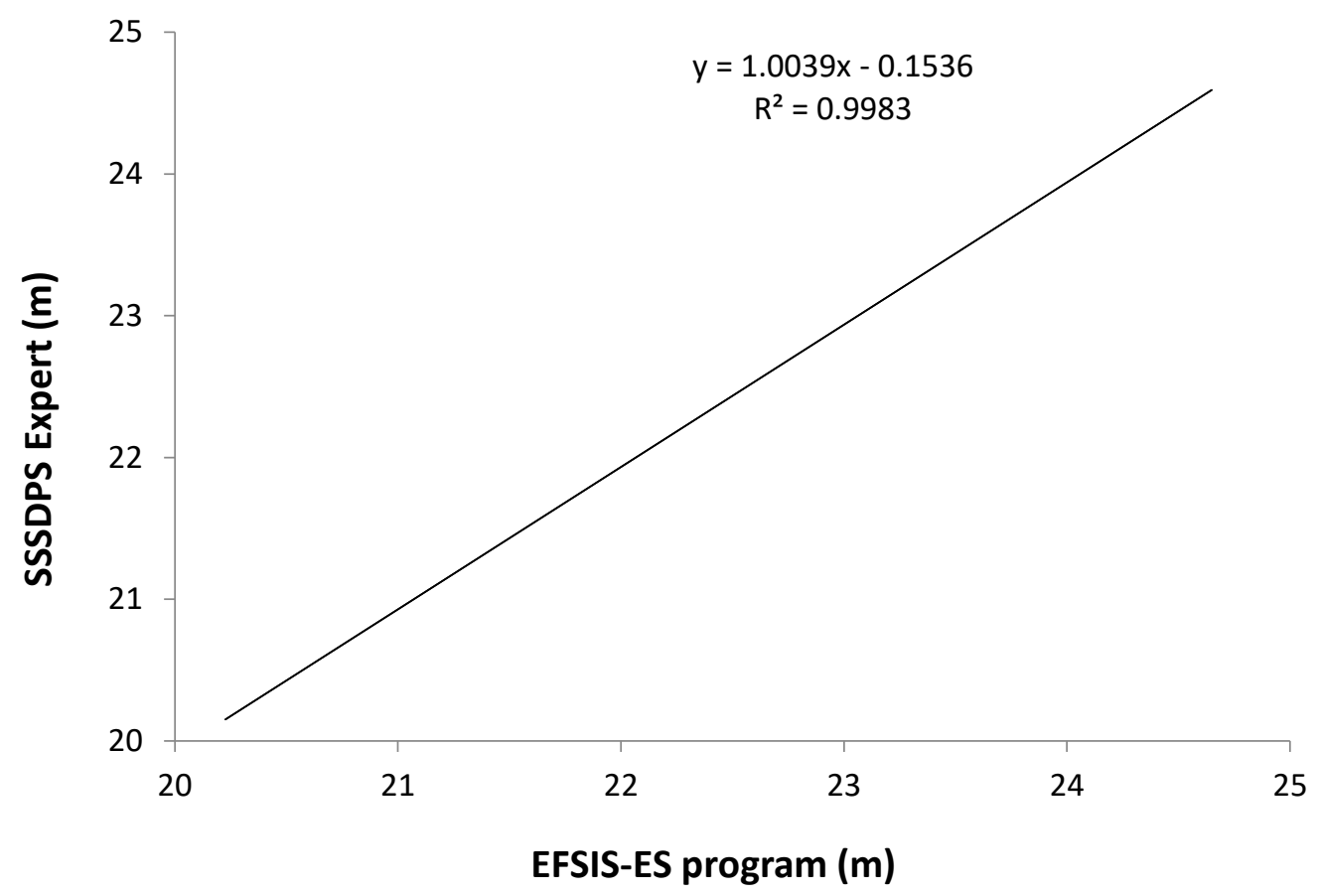

Fig 9. The regression analysis between EFSIS-ES program and SSSDPS Expert regarding total dynamic head (TDH) (m) 


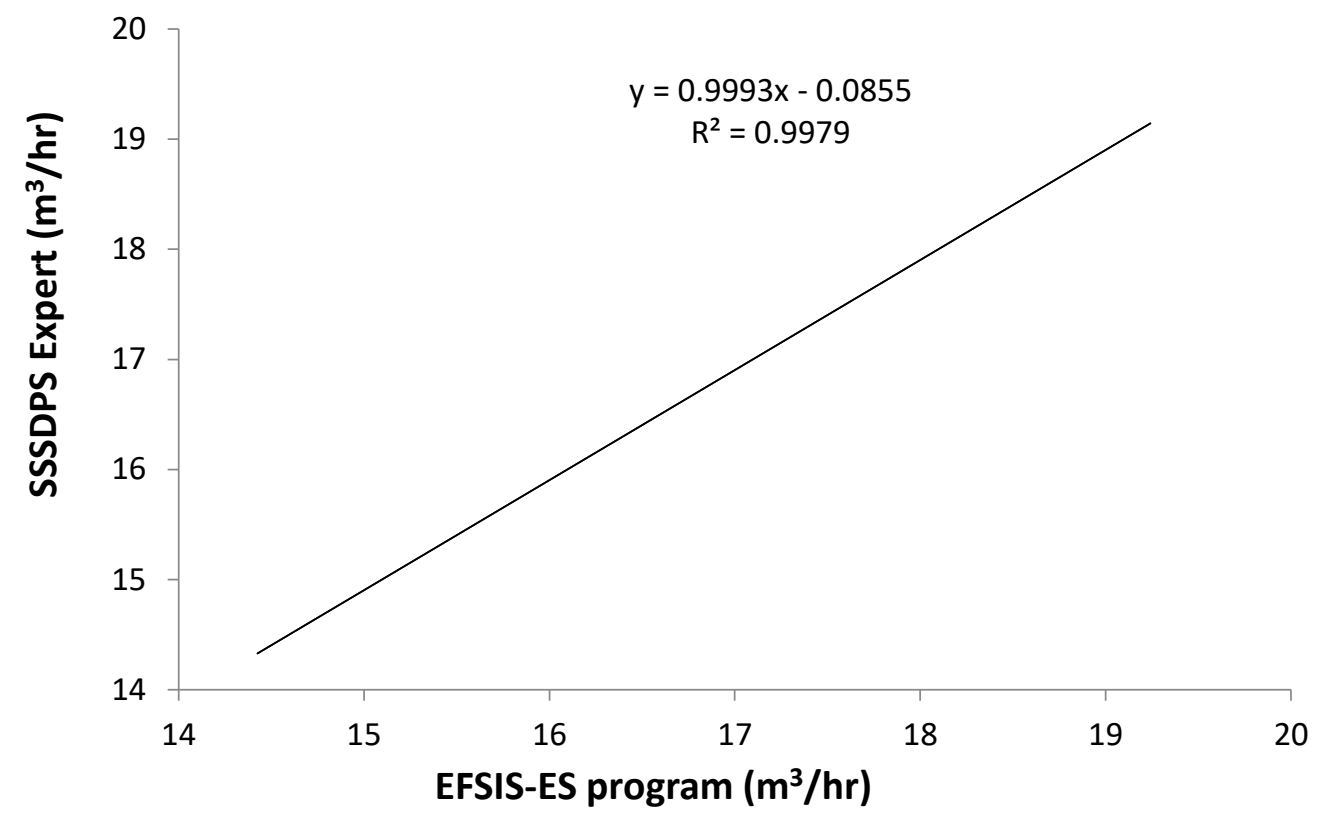

Fig 10. The regression analysis between EFSIS-ES program and SSSDPS Expert regarding pump discharge output $\left(\mathrm{m}^{3} / \mathrm{hr}\right)$

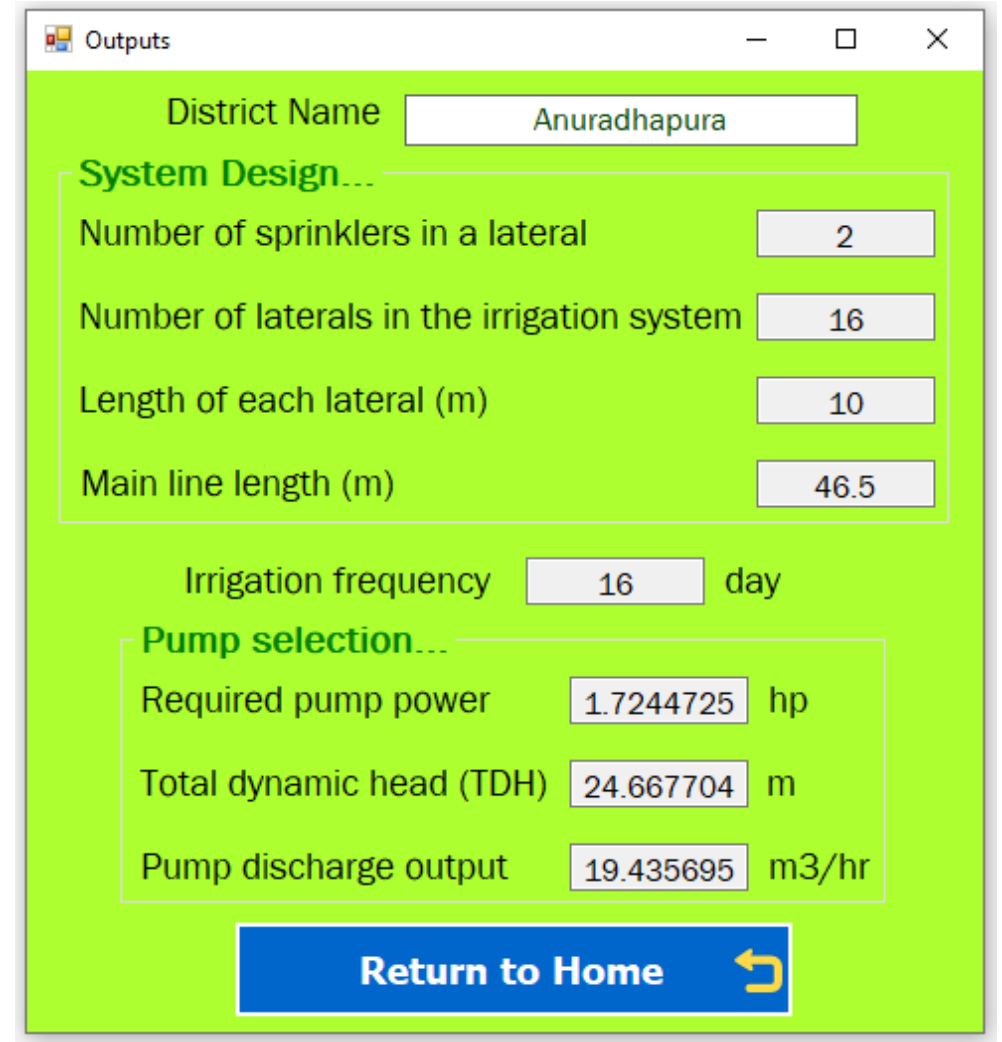

Fig 11. Outputs generated by using EFSIS-ES program

AUJASCI, Arab Univ. J. Agric. Sci., 29(1), 2021 


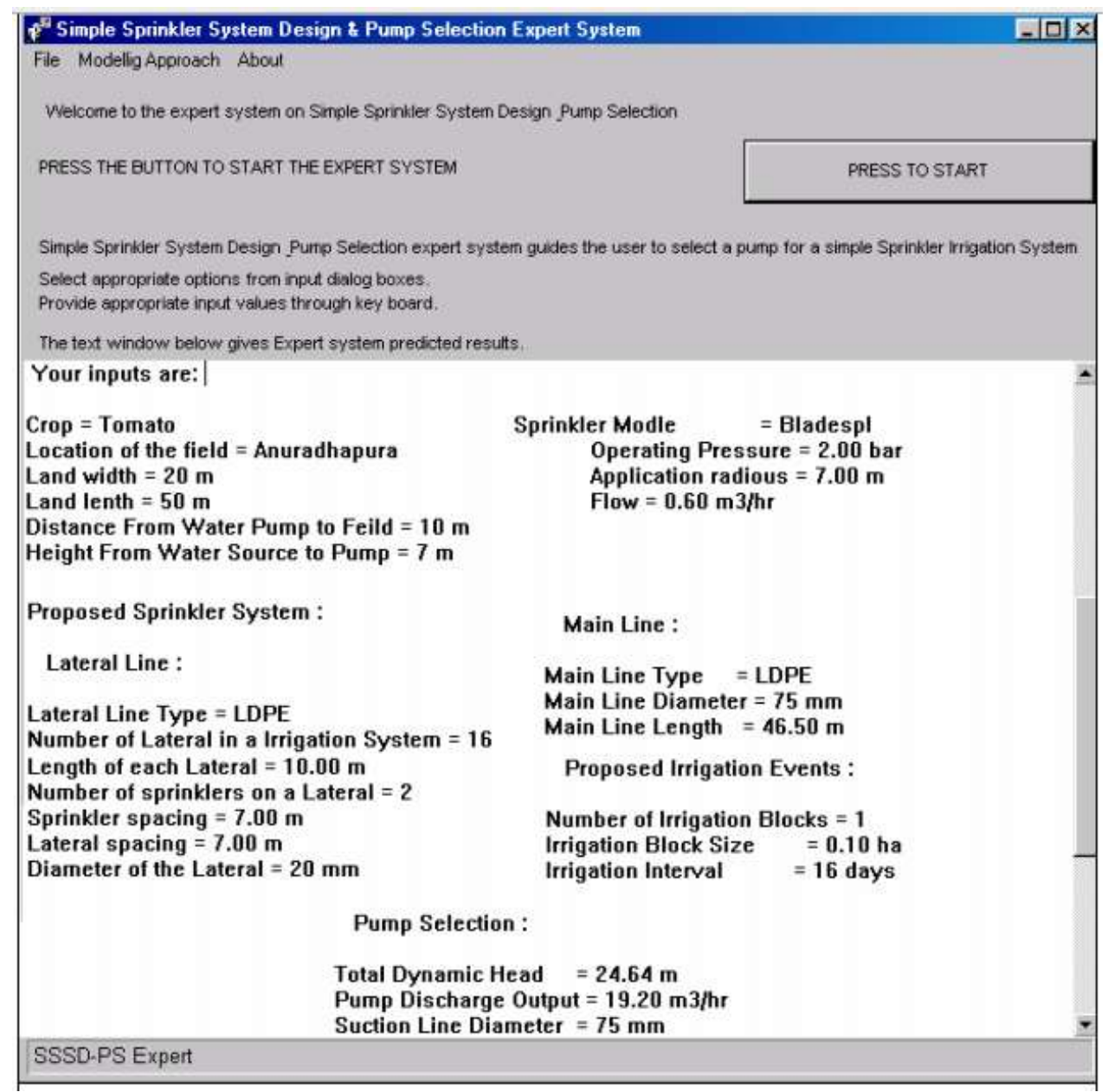

Fig 12. Outputs generated by using SSSDPS Expert

\section{Conclusions}

The problems faced in sprinkler irrigation systems designing because of lack of persons technically qualified have created the need to expert system for this purpose. This preliminary study focuses mainly on design of such expert system for making a decision for the normal user to maximize the system efficiency of sprinkler irrigation. The EFSIS-ES program contains of inputs screens and outputs screen. Inputs screens are the interface screen, inputs screen, location screen, climate screen, pump screen, crop screen, soil screen and sprinkler system screen. Results indicated that the computer program technology can be applied for designing the system of sprinkler irrigation under specified field conditions with high accuracy of investigation. This system can help non-technical users and sprinkler irrigation system installers to come up with better system layouts for productivity maximization with the available resources.

\section{References}

Abeyrathne, BGA; Najim, MMM; Jayatissa, DN (2005) Development of a simple sprinkler system designing and pump selection expert system (SSSDPS Expert). Water Professionals' Day Symposium, Water Resources Research in Sri Lanka, 1-13. 
Cuenca, RH (1989) Irrigation System Design, an Engineering Approach. Prentice Hall, Inc, Englewood Cliffs, NJ, pp 30-61.

Doukhan, AZ (2010) Expert System for Managing Chemigation Systems. Ph.D. in Agric Eng, Agric Eng Dept, Fac of Agric, Ain Shams Univ, Egypt, pp 38-45.

Eid, SF; Abdrabbo, MA (2018) Developments of an expert system for on-farm irrigation water management under arid conditions. $J$ Soil Sci and Agric Eng 9, 69-76.

El-Bagoury, KF (2004) The Use of Expert System to Improve Farm Irrigation Technologies for Maximizing Water Use Efficiency of Field Crops under Drought Conditions in Egypt. Ph.D. in Agric Eng, Agric Eng Dept, Fac of Agric, Ain Shams Univ, Egypt, pp 110115.

El-Tohamy, KM (2016) An Expert System for Managing On-Farm Irrigation Water of Some Oil Crops. M.Sc. in Agric Eng, Agric Eng Dept, Fac of Agric, Ain Shams Univ, Egypt, pp 110-125.

Gutierrez-Estrada, JC; De Pedro San, E; Luquec, R; Pulido-Calvo, I (2005) SED- PA: an expert system for disease diagnosis in eel rearing systems. Aquacultural Eng 33, 110125.

Kara, T; Ekmekci, E; Apan, M (2008) Determining the uniformity coefficient and water distribution characteristics of some sprinklers. Pakistan Journal of Biological Sciences 11, 214-219.

Khamkar, NU (2014) Design and implementation of expert system in irrigation of sugarcane: Conceptual study. Sinh Gad Institute of Management and Computer Application (SIM CA), pp 55-58.
Li, M; Guo, P; Singh, V (2016) An efficient irrigation water allocation model under uncertainty. Agricultural systems 144, 46-57.

Motameni, H (2010) A rule Based Expert System for Mobilization of Construction. M.Sc. in Science, Civil Engineering Dept., Fac. of Engineering, Eastern Mediterranean University, pp 1-55.

Phillips-Wren, G (2012) Ai Tools in Decision Making Support Systems: a Review. International Journal of Artificial Intelligence Tools 21, 1240005(1-13).

Ragab, SA (2017) An Expert System for Selecting the Technical Specifications of Drip Irrigation Control Unit. M.Sc. in Agric Eng, Dept of Agric Eng, Fac of Agric, Ain Shams University, pp 100-115.

Seraj-Rezaei, Y; Delirhasannia, R; Sadraddini, A; Fakheri-Fard, A (2014) Comparative analysis of some commonly used impact sprinklers performances in the different wind conditions and sprinkler arrangements. Journal of Applied Biological Sciences 8, 38-44.

Shervan, FE; Hadi, T; Shahram, J (2013) Design and Development of an Expert System to Help Head of University Departments. International Journal of Science and Modern Engineering (IJISME) 1, 15-23.

Van de Giesen, N; Stomph, T; Ajayi, AE; Bagayoko, F (2011) Scale effects in Hortonian surface runoff on agricultural slopes in West Africa: Field data and models. Agriculture, Ecosystems \& Environment 142, 95-101. 


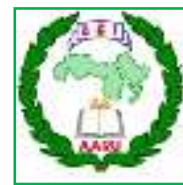

مجلة اتحاد الجامعات العربية للعلوم الزراعية، جامعة عين شمس، القاهرة، مصر مجلد(29)، عدد(1)، 197 - 210، 2021 إمعه عينة

Website: http://ajs.journals.ekb.eg

DOI: $10.21608 /$ ajs.2021.48681.1288

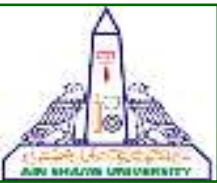

210

تصميم نظم الري بالرش باستخذام برنامج نظام خبير

[12]

محمد جابر الأشرم1" - خالد فران الباجوري2 - سعيد محمد شعبان 1 - أحمد أبوالحسن عبدالعزيز2

1- قسم العلاقات المائية والري الحقلي - المركز القومي للبحوث - الدقي - الجيزة - مصر

2- قسم الهندسة الزراعية -كلية الزراعة - جامعة عين شمس - ص.ب 68 - حدائق شبرا 11241 - القاهرة - مصر

*Corresponding author: alashram.mgmnrc@yahoo.com

Received 6 November, 2020

Accepted 18 January, 2021

المضـخة المطلوبة، الضـغط الديناميكي الكلي (TDH)

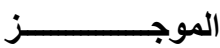

والتصــرف المســخرج من المضـــة. وأظهرت النتائج

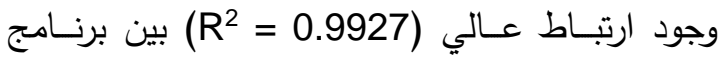

في هذا البحث تم بناء وتدقيق وتقييم نظام خبير

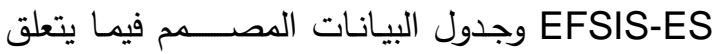

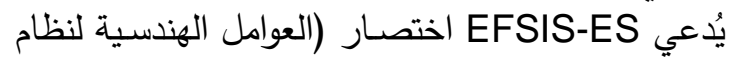

بالفترة بين الريات. يمكن الإشارة إلى وجود ارتباط عالي

الري بالرش - نظام خبير). بناءا علي ذلك فإن الهدف

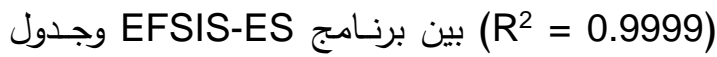

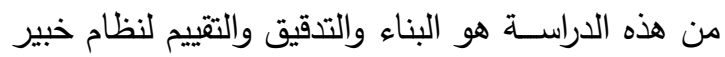

البيانات المصمم فيما يتعلق بقدرة المضخة. كان معامل

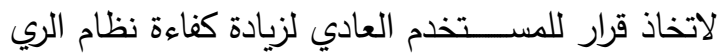

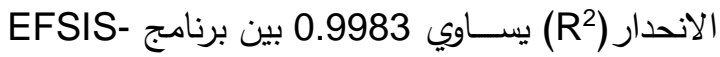

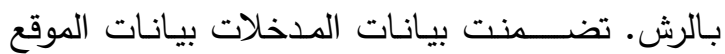

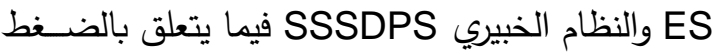

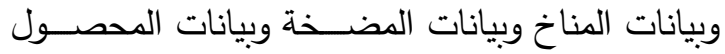

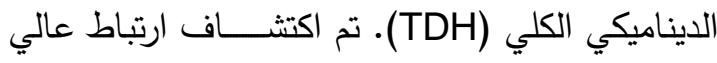

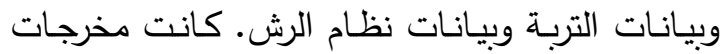

بين برنـامج (RS = 0.9979)

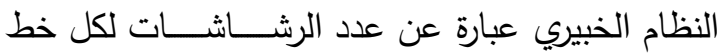

الخبيري SSSDPS فيما يتعلق بالتصــرف المسـتخرج

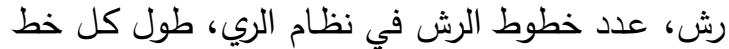

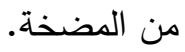

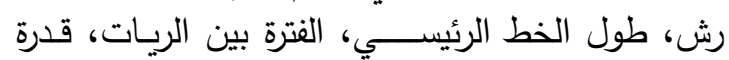

